\title{
ANTIOXIDANT ACTIVITY AND PHYSICOCHEMICAL CHARACTERISTICS OF BURITI PULP (Mauritia flexuosa) COLLECTED IN THE CITY OF DIAMANTINO - MTS ${ }^{1}$
}

\author{
DAYANE DE OLIVEIRA SANDRI ${ }^{2}$, ANDREA LUIZA RAMOS PEREIRA XISTO ${ }^{3}$, \\ ERIKA CRISTINA RODRIGUES ${ }^{4}$, ELAINE CARVALHO DE MORAIS ${ }^{5}$, \\ WANDER MIGUEL DE BARROS ${ }^{6}$
}

ABSTRACT - Buriti is a fruit with potential for economic exploitation due to its nutritional components; however, there are few studies about their post-harvest characteristics. Thus, the aim of this study was to determine the physicochemical characteristics and analyze the antioxidant activity of Buriti pulp. Fruits were harvested at full maturity stage, sanitized, pulped and stored under refrigeration until freezing. Then, pulp was submitted to the following analyses: moisture, protein, total carbohydrates and reducing carbohydrates, ashes, lipids, crude fiber, water activity, titratable acidity (TA), $\mathrm{pH}$, color, $\beta$-carotene, $\alpha$-carotene, antioxidant activity and total energy value (TEV). Analyses were performed in triplicate, and the mean, standard deviation and variation coefficient were determined. Fruit pulp presented 0.98 of water activity, TA of $8.82 \mathrm{~g} / 100 \mathrm{~g}$ of citric acid, $\mathrm{pH} 3.78,59.69 \%$ of moisture, $20.92 \%$ of fat, $8.56 \%$ of crude fiber, $1.04 \%$ of ash, $7.28 \%$ of total carbohydrates, $4.50 \%$ of reducing carbohydrates, $9098 \mu \mathrm{g} / 100 \mathrm{~g}$ of $\beta$ carotene and $10086 \mu \mathrm{g} / 100 \mathrm{~g}$ of $\alpha$-carotene. TEV found was $228.28 \mathrm{kcal} / 100 \mathrm{~g}$, the color analysis showed that the pulp has an average light tint value of $\mathrm{L}^{*}=59.69$, with high hue $\mathrm{H}^{*}=68.36$ and vivid color with $\mathrm{C} *=62.03$. Regarding the antioxidant activity, it was observed that Buriti is a fruit that can be used to combat oxidation, as it reduced by $82.42 \%$ the amount DPPH reagent used.

Index Terms: DPPH reduction; calorific value; proximate composition.

\section{ATIVIDADE ANTIOXIDANTE E CARACTERIZAÇÃO FÍSICO QUÍMICA DE POLPA DE BURITI (MAURITIA FLEXUOSA) COLETADO NA CIDADE DE DIAMANTINO - MT}

\begin{abstract}
RESUMO - O Buriti é um fruto com potencial para exploração econômica, devido aos seus componentes nutricionais; no entanto, poucas são as pesquisas quanto a suas características pós-colheita. Sendo assim, o objetivo deste trabalho foi determinar as características físicas e químicas e analisar a atividade antioxidante da polpa de buriti. Os frutos foram colhidos em completo estádio de maturação, sanitizados, despolpados e armazenados sob refrigeração até o congelamento. Em seguida a polpa foi submetida às análises de umidade, proteína, glicídios totais e redutores, cinzas, lipídios, fibra bruta, atividade de água, acidez titulável (AT), $\mathrm{pH}$, cor, $\beta$ caroteno, $\alpha$ caroteno, atividade antioxidante e valor energético total (VET). As análises foram realizadas em triplicata, sendo determinadas a média, desvio-padrão e o coeficiente de variação. A polpa da fruta apresentou valores de 0,98 para atividade de água, AT de 8,82 g/100g de ácido cítrico, $\mathrm{pH}$ de 3,78, $59,69 \%$ para umidade, $20,92 \%$ de lipídios, $8,56 \%$ de fibra bruta, 1,04\% de cinzas, 7,28\% de glicídios totais, $4,50 \%$ para glicídios redutores, $9098 \mu \mathrm{g} / 100 \mathrm{~g}$ de $\beta$ caroteno e $10086 \mu \mathrm{g} / 100 \mathrm{~g}$ de $\alpha$ caroteno. O VET encontrado foi de $229,28 \mathrm{Kcal} / 100 \mathrm{~g}$, a análise de cor mostrou que a polpa possui tonalidade clara com valor médio de $\mathrm{L}^{*}=59,69$, alta tonalidade cromática $\operatorname{com~} \mathrm{H}^{*}=68,36$ e cor viva com $\mathrm{C}^{*}=62,03$. Quanto à atividade antioxidante, observou-se que o buriti é um fruto que pode ser utilizado no combate a oxidação, pois reduziu em $82,42 \%$ a quantidade do reagente DPPH utilizado.
\end{abstract}

Termos para Indexação: redução de DPPH; valor calórico; composição centesimal.

\footnotetext{
'(Paper 005-16). Received January 11, 2016. Accepted June 23, 2016.

${ }^{2}$ Master in Food Science and Technology. Federal Institute of Mato Grosso. Email: dayanesandri@gmail.com

${ }^{3} \mathrm{PhD}$ in Food Science, Professor at the Federal Institute of Mato Grosso. Email: andrea.xisto@cas.ifmt.edu.br r;

${ }^{4}$ PNPD / CAPES Fellow in Food Science, Professor at the Federal Institute of Mato Grosso. Email: erika.rodrigues@blv.ifmt.edu.br

${ }^{5} \mathrm{MSc}$ in Food Science and Technology. Federal Institute of Mato Grosso. Email: elaine_carvalho.2@hotmail.com

${ }^{6} \mathrm{PhD}$ in Health Sciences. Professor at the Federal Institute of Mato Grosso. Email: wander.barros@blv.ifmt.edu.br
} 


\section{INTRODUCTION}

Buriti (Mauritia flexuosa L.) belongs to family Arecaceae and genus Mauritia, with wide distributed in the Amazonian Forest of Brazil. It is a plant of wide distribution in the national territory, being found in Cerrado, western Caatinga, Pantanal and Amazon biomes. This species is found in wetland areas in regions of trails, an important Cerrado phytophysiognomy. Buriti blooms almost all year, but mainly from April to August. Fruit production is intense, producing seven bunches per year per tree, each with 400 to 500 fruits (SAMPAIO, SCHMIDT, FIGUEIREDO, 2008; DELGADO et al., 2007).

Fruits have an orange-colored thick mass and spongy endocarp that surrounds the very hard seed. Buriti has adequate nutritional values, especially carotenoids and ascorbic acid. Carotenoids, in addition to being natural dyes, have beneficial effects on human health such as provitamin A activity, increased immune response and reduced risk of degenerative diseases such as cancer, muscle degeneration, cataracts and cardiovascular diseases. Ascorbic acid, also called vitamin C, is important in the formation of teeth and bones and in the prevention of diseases such as scurvy, influenza and heart diseases (LIMA et al., 2009).

Among the various native fruits of the Amazon, Buriti is very useful, and almost all parts can be used, including trunk, from which starch and palm heart are extracted (LOUREIRO et al., 2013). Buriti pulp is also used in the industrial extraction of oil. Albuquerque et al. (2005) characterize the fruit as raw material for the production of biodiesel. The use of Buriti pulp in the generation of food by-products has been restricted to small productions, being an activity present in family agriculture programs or small companies.

According to Canuto et al. (2010), the characterization of parameters for quality control, involving physical and physicochemical properties, as well as compounds with functional interest and antioxidant activity for pulps of Amazonian fruit species allows characterizing these products as functional food and offers the option of sustainable activity for the population of these regions. Therefore, the aim of this work was to evaluate the physicochemical characteristics of Buriti pulp and to analyze its potential for oxidation inhibition.

\section{MATERIAL AND METHODS}

Buriti (Mauritia flexuosa L.) was collected in the city of Diamantino, Mato Grosso (MT), in February 2014, at full maturation stage. After collection, fruits were selected, sorted and sanitized in water added of sodium hypochlorite in the proportion of 5-10 L of water per $1 \mathrm{~kg}$ of fruit, containing $150 \mathrm{mg} / \mathrm{L}$ of sodium hypochlorite for 2 minutes. Then, fruits were peeled and pulped, and the pulp was packed in low-density polyethylene bags and frozen at $-18^{\circ} \mathrm{C}$. By road transport, frozen pulps were sent to the Federal Institute of Mato Grosso (IFMT), located in the city of Cuiabá - MT, where they were analyzed.

Physicochemical analyses were performed according to methodology described by Instituto Adolfo Lutz (IAL, 2008) and Official Method of Analysis (AOAC, 2012) in triplicate.

The moisture content was determined by the gravimetric method, which consists of drying in an oven (Nova Ética) at temperature of $105^{\circ} \mathrm{C}$ to constant weight, method 012 / IV (IAL, 2008). The ash content was quantified by gravimetry through incineration of the sample in a Quimis muffle oven at $550^{\circ} \mathrm{C}$, method $018 / \mathrm{IV}$ (IAL, 2008).

The color of samples was determined by instrumental measurement using Minolta CM - 700D colorimeter, where readings were determined in $\mathrm{L}^{*}$ (luminosity) a $*$ (transition from green - a $*$ to red + $\mathrm{a} *$ ) and $\mathrm{b} *$ (transition from blue $-\mathrm{b} *$ to yellow $+\mathrm{b}$ $*)$. From parameters obtained $\left(\mathrm{L}^{*}, \mathrm{a} *\right.$ and $\left.\mathrm{b} *\right)$, the chromatic hue $\mathrm{h} *=\tan -1(\mathrm{~b} * / \mathrm{a} *)$ and saturation $\mathrm{C}^{*}=\left(\mathrm{a}^{* 2}+\mathrm{b}^{* 2}\right)^{1 / 2}$ were calculated.

The water activity (Aw) was analyzed using the Aqualab 3TE water activity analyzer (Decagon), with sample at room temperature $\left(25^{\circ} \mathrm{C}\right)$, method 978.18 (AOAC, 2012).

Total Titratable Acidity was quantified using the neutralization volumetry technique with standard sodium hydroxide $(\mathrm{NaOH})$ solution of $0.1 \mathrm{~N}$ and expressed as a percentage of citric acid by the method 016 / IV (IAL, 2008). The vitamin C content was determined by oxidation - reduction volumetry using $0.02 \mathrm{M}$ potassium iodate and $1 \%$ starch solution as indicator, method 364 / IV (IAL).

The $\mathrm{pH}$ was measured by direct potentiometry, using a Tecnal $\mathrm{pH}$ meter apparatus previously calibrated with $\mathrm{pH} 4.0$ and 7.0 buffer solutions.

The protein percentage was determined by the Kjeldahl method (Tecnal, model TE 0363), using conversion factor of 6.25 for food in general, method 036 / IV (IAL, 2008). 
The lipid content was determined by soxhlet extraction (Tecnal, model TE 044) using petroleum ether as a solvent extractor by the method 032 / IV (IAL, 2008).

Total fiber content was determined by acid digestion followed by basic digestion and oven drying at $105^{\circ} \mathrm{C}$ to constant weight, method 044 / IV (IAL, 2008).

The quantification of reducing and total sugars was performed using the oxidation - reduction volumetric technique using the Fehling method, methods 038 / IV and 039 / IV (IAL, 2008).

The antioxidant activity (DPPH) was determined by DPPH assay (1,1-diphenyl-2picrylhydrazyl), with reading in UV-visible spectrophotometer (UV-1800, Shimadzu) at $517 \mathrm{~nm}$ wavelength, according to methodology described by Illupapalayam, Smith and Gamlath (2014).

The $\beta$ carotene content was determined by direct reading of ethereal extract of Buriti pulp in a Shimadzu spectrophotometer model UV 1800 with wavelength of $453 \mathrm{~nm}$, using the calculation: $(\beta$ carotenes, $\mu \mathrm{g} / 100 \mathrm{~g})=(($ Extract absorbance $\mathrm{x} 50 \mathrm{x}$ $\left.10^{4}\right) /(2592 \mathrm{X}$ sample weight) $\mathrm{x} 100$, methodology proposed by Pacheco et al. (2011).

The $\alpha$-carotene content was determined by direct reading of ethereal extract of Buriti pulp in a Shimadzu 800 spectrophotometer model UV 1 with wavelength of $444 \mathrm{~nm}$, using the calculation: $(\beta$ carotenes, $\mu \mathrm{g} / 100 \mathrm{~g})=(($ Extract absorbance x $50 \mathrm{x}$ $\left.10^{4}\right) /(2400 \mathrm{X}$ sample weight) $\mathrm{x} 100$, methodology proposed by Pacheco et al. (2011).

Total Energy Value (TEV) was calculated according to the Atwater equation based on the traditional conversion factors for protein $(4 \mathrm{Kcal} / \mathrm{g})$, lipid (9Kcal / g) and carbohydrates (4Kcal / g), and expressed in Kcal / 100g, according to RDC No. 360 of the Ministry of Health.

\section{RESULTS AND DISCUSSION}

The results obtained for the physical and physicochemical characteristics of Buriti pulp can be observed in table 1 .

According to table 1 it can be observed that Buriti pulp presented high moisture value, reaching $59.69 \%$. This result is similar to that found by Carneiro and Carneiro (2011), who obtained moisture content around $54.34 \%$, analyzing Buriti pulp from the region of Ipiranga, Piauí, differing from Tavares et al. (2003), who found moisture content of $67.2 \%$ for Buriti from the city of Buritizal - SP; and Mariath et al. (1989), who found moisture content of $69.6 \%$ for Buriti from in the region of São Luiz, Maranhão, and Manhães (2007) reported 62.93\% for Buriti pulp from the state of Pará.

The protein percentage found was $2.97 \%$, a result higher than those found by different authors, among them Carneiro and Carneiro (2011), who found $1.30 \%$; Mariath et al. (1989) with value of $1.80 \%$; Tavares et al. (2003), with value of $1.4 \%$ and Manhães (2007) with value close to $2.10 \%$.

The percentage of lipids is the second largest component of the proximate composition in terms of quantity in the Buriti pulp analyzed and represents all substances soluble in organic solvent, including oils and fats, carotenoids, chlorophyll and other pigments, in addition to sterols, phosphatides, liposoluble vitamins among others (IAL, 2008). The amount of lipids found in the Buriti pulp analyzed was $20.92 \%$, being higher than values described by Mariath et al. (1989) and by Manhães (2007) of $8.10 \%$ and $13.85 \%$, respectively. Some factors may contribute to the difference between values found and those available in literature. In addition to the possible dehydration of fruits during transportation and storage stages, the methodologies used may have been different, which may have contributed to difference in results found. The lipid concentration of Buriti pulp should be valued, as oils and fats are the main source of energy available to the human body and are useful for industry due to the presence of aromatic compounds that change the physical consistency of several products (FRANÇA et al., 1999).

The percentage of ash, also known as fixed mineral residue, was $1.04 \%$, similar to $0.94 \%$ found by Manhães (2007) and $1.05 \%$ by Castro et al. (2014).

The group of sugars has the most varied types of substances, from monosaccharides, represented by glucose, disaccharides, of which the most frequent in foods are sucrose and lactose, to polysaccharides such as starch and cellulose (IAL, 2008). According to Silva et al. (2008) monosaccharides (glucose and fructose) are reducing sugars that, due to the presence of free carbonyl and ketone groups, are able to oxidize in the presence of oxidizing agents in alkaline solutions. Some disaccharides, such as sucrose, do not have this characteristic, hence called non-reducing sugars, and are reduced only after they undergo hydrolysis of the glycosidic bond. Therefore, the amount of reducing and total carbohydrates of the Buriti pulp was analyzed, presenting values of $4.50 \%$ and $7.28 \%$, respectively, and for total glycans, the values found in this study are close to those reported by Manhães (2007), who found value of $8.25 \%$, but for reducing sugars, the value was higher, $3.01 \%$. The total sugar content found in this work is lower 
than that found by Carneiro and Carneiro (2011), who found $25.53 \%$ of lipids for Buriti pulp; Mariath et al. (1989) found 19.8\%; and Tavares et al. (2003) found $12.1 \%$ of carbohydrate in Buriti pulp. According to Magro et al. (2006), these differences observed in both total and reducing sugar content are mainly due to the origin of samples, since climatic conditions, especially insolation, influence the production of sugars by fruits, as well as the degree of maturation.

Table 1 shows that the total fiber content of Buriti pulp was $8.56 \%$. In studies with tropical fruits, Uchoa et al. (2008) analyzed the percentage of crude fiber in different cashew (9.92\%), guava $(39.56 \%)$ and Maracuja (26.31\%) fruits, showing that the result found in this study is similar to that found for cashew fruits. Lima (2006) analyzed the percentage of fibers in oleaginous fruits, such as avocado, pequi and coconut and obtained values of $6.3 \%, 19 \%$ and $5 \%$, showing that the value found for Buriti in this study $(8.56 \%)$ is among values found for oleaginous fruits.

The TEV of the Buriti analyzed was 229.28 Kcal / 100g. Mariath et al. (1989) analyzed the chemical composition of Buriti marketed in the state of Maranhão and found TEV of $145 \mathrm{Kcal}$, much lower than that of this study, considering that the most expressive caloric nutrient in the fruit, lipids, presented a lower value. Manhães (2007) found TEV of 166.36 Kcal for Buriti pulp marketed in the state of Pará.

Studies also reveal a high water activity for the Buriti pulp analyzed, presenting a value of 0.98 . In a study with Buriti pulp from the state of Ceará, Castro et al. (2014) found Aw of 0.99, a value similar to that found in this work. Fellows (2006) reported that the water activity is an important factor for controlling the deterioration rate of the product, and generally foods with water activity higher than 0.95 are classified as fresh and highly perishable food and tend to undergo rapid deterioration, which is the case of fruits such as Buriti.

The titratable acidity (TA) value found was $8.82 \mathrm{~g} / 100 \mathrm{~g}$ of citric acid, a result higher than that found by Castro et al. (2014), who found value of 1.48. According to Sousa et al. (2013), acidity is an important parameter in the assessment of the state of conservation of a food product.

The $\mathrm{pH}$ found (3.78) is close to that found by Castro et al. (2014) of 3.47 for Buriti pulp. For Buriti pulp, the average $\mathrm{pH}$ value found (3.78) classifies the pulp as acid, which for the processing industry represents an excellent attribute since microbial deterioration is hampered in acid media.

The antioxidant activity of a substance corresponds to the amount of DPPH consumed during a certain time. The amount of antioxidant needed to reduce the initial DPPH concentration by $50 \%$ is called the effective concentration $\left(\mathrm{EC}_{50}\right)$, also called inhibitory concentration $\left(\mathrm{IC}_{50}\right)$. The higher the $\mathrm{DPPH}$ consumption by a sample, the lower its $\mathrm{EC}_{50}$ and the higher its antioxidant activity (SOUSA et al., 2007). The $\mathrm{EC}_{50}$ of Buriti pulp was determined in 30 minutes. Studies involving acerola and grape pulp stand out in the evaluation of the antioxidant activity, with more than $90 \%$ of DPPH radical sequestration after 30 minutes (VARGAS, HELZEL, ROSA 2008). Duarte Almeida et al. (2006) found high antioxidant activity in acerola extract, followed by mulberry, açaí and strawberry extracts. The antioxidant activity value found for Buriti pulp was $82.42 \%$, showing that this fruit presents high percentage of oxidation inhibition

Analyzing Table 1, it can be observed that the amount of vitamin $\mathrm{C}$ found for Buriti pulp analyzed in this study was $46.67 \mathrm{mg} / 100 \mathrm{~g}$, a value higher than that found by Couto et al. (2010) in studies with tangerine $(32.47 \mathrm{mg} / 100 \mathrm{~g})$, and lower than that found by Yamashita et al. (2003) in studies with acerola, $1511 \mathrm{mg} / 100 \mathrm{~g}$, noting that acerola is known to be source of this vitamin. According to Itto et al. (1990), the vitamin C content is mainly related to the stage of maturation, storage and period of analyses, since vitamin $\mathrm{C}$ is extremely sensitive and can be easily oxidized.

The color analysis is determined by three parameters $(\mathrm{L} *, \mathrm{a} *$ and $\mathrm{b} *)$, which are provided by direct reading in colorimeter apparatus, being precursors of parameters $\mathrm{h} *$ and $\mathrm{C} *$ calculated from mathematical equations. Parameter $\mathrm{L} *$ representing luminosity in the color analysis revealed characteristics of a pulp with light tint, with mean value of $59.69 \pm 0.01$, because the closer to 100 , the greater the sample clarity. Parameter $\mathrm{H} *$ observed for Buriti pulp showed a high chromatic hue (68.36 \pm 0.005 ); Canuto et al. (2010) reported that positive $\mathrm{H} *$ values indicate variation from yellow to slightly orange. The chroma value $(\mathrm{C} *)$ found $(62.03 \pm$ 0.02 ) reveals a vivid color for the pulp. These results are similar to those found by Castro et al. (2014), with $\mathrm{L} *=43.89, \mathrm{~h} *=74.55$ and $\mathrm{C} *=65.65$, and although values were slightly higher, the colorimetric characteristics of the pulp analyzed in this study showed similar values.

The $\alpha$ and $\beta$ carotene content found in this study were $10086 \mu \mathrm{g} / 100 \mathrm{~g}$ and $9098 \mu \mathrm{g} / 100 \mathrm{~g}$, respectively. Lima et al. (2009) studied Buriti from the state of Goiás and found $\beta$ carotene values of $31220 \mu \mathrm{g} / 100 \mathrm{~g}$ and $\alpha$ carotene values of 5352 $\mu \mathrm{g} / 100 \mathrm{~g}$, being both higher than those found in 
this work. Agostini-Costa et al. (2003) studied the influence of freezing and storage on the $\alpha$ and $\beta$ carotene content in acerola pulp and found that over time, there may be a reduction of up to $63 \%$ in $\beta$ carotene content, and there is no loss of $\alpha$ carotene. According to Ângelo and Jorge (2007), the methodology of analysis of any type of food can directly influence the results obtained, since chromatographic apparatuses are more precise and meticulous when compared to analyses performed in conventional way. Therefore, the low amount of $\beta$ carotene found in this study when compared to literature can be justified due to freezing followed by storage, as well as to the methodology used in the quantification of compounds.

TABLE 1 - Physical and physicochemical characteristics of buriti pulp.

\begin{tabular}{ccc}
\hline Characteristics & Mean & VC \\
\hline Moisture (\%) & $59.69 \pm 0.64$ & 1.08 \\
Protein (\%) & $2.97 \pm 0.39$ & 6.23 \\
Lipids (\%) & $20.92 \pm 0.72$ & 3.47 \\
Ash (\%) & $1.04 \pm 0.04$ & 3.62 \\
Total sugars (\%) & $7.28 \pm 0.07$ & 0.97 \\
Reducing sugars (\%) & $4.50 \pm 014$ & 3.19 \\
Gross Fiber (\%) & $8.56 \pm 015$ & 1.82 \\
Water Activity (Aw) & $0.98 \pm 0.02$ & 0.16 \\
pH & $8.82 \pm 0.16$ & 1.89 \\
$\mathrm{~L}^{*}$ & $3.78 \pm 0.04$ & 0.95 \\
$\mathrm{a}^{*}$ & $59.68 \pm 0.75$ & 0.01 \\
$\mathrm{~b}^{*}$ & $22.87 \pm 2.12$ & 0.72 \\
$\mathrm{~h}^{*}$ & $57.66 \pm 1.92$ & 1.78 \\
$\mathrm{C}^{*}$ & $68.36 \pm 0.38$ & 0.005 \\
Titratable Acidity $(\mathrm{g} / 100 \mathrm{~g}$ citric acid) & $62.03 \pm 1.32$ & 0.02 \\
$\%$ oxidation inhibition $(\mathrm{DPPH})$ & $82.42 \pm 0.04$ & 2.27 \\
Vitamin C $(\mathrm{mg} / 100 \mathrm{~g})$ & $49.67 \pm 0.92$ & 2.4 \\
$\beta$ carotene $(\mu \mathrm{g} / 100 \mathrm{~g})$ & $9098 \pm 1.03$ & 0.47 \\
$\alpha$ carotene $(\mu \mathrm{g} / 100 \mathrm{~g})$ & $10086 \pm 0.92$ & 1.45 \\
TEV $(\mathrm{Kcal})$ & 229.28 & - \\
\hline
\end{tabular}

$\mathrm{L}^{*}$ : Luminosity index; a *: Red color tint; $\mathrm{B}$ *: yellow color tint; $\mathrm{H}$ *: chromatic hue angle; $\mathrm{C}$

*: Saturation.

\section{CONCLUSION}

Buriti (Mauritia Flexuosa) is a fruit with excellent nutritional quality and richness of nutrients, proven by its proximate composition, showing that its consumption should be encouraged, since it provides an appreciable amount of nutrients and meets the needs of modern consumers for fruits rich in antioxidant compounds and fibers.

The amount of carotenoid compounds found is satisfactory, since the American Institute of Medicine recommends that each individual over 14 years of age should consume around $900 \mu \mathrm{g}$ of carotenoids per day. These carotenoids are also classified as antioxidants, thus confirming the antioxidant potential of this fruit.

\section{ACKNOWLEDGMENTS}

The authors would like to thank the Coordination for the Improvement of Higher Education Personnel (CAPES) for the granting of scholarship and the Federal Institute of Education, Science and Technology of Mato Grosso for the facilities and equipment.

\section{REFERENCES}

AgOSTINI-COSTA, T.; DE ABREU, L. N.; ROSSETTI, A. G. Efeito do congelamento e do tempo de estocagem da polpa de acerola sobre o teor de carotenóides. Revista Brasileira de Fruticultura, Jaboticabal, v.25, n.1, p.56-8, 2003. 
ALBUQUERQUE, M.L.; GUEDES, I. ; ALCANTARA JUNIOR, P.; MOREIRA, S.G.C.; BARBOSA NETO, N.M.; CORREA, D.S.; ZILIO, S.C. Characterization of buriti (Mauritia flexuosa L.) oil by absorption and emission spectroscopies. Journal of Brazilian Chemical Society, Campinas, v.16, n.6A, p.1113-1117, 2005.

ANGELO, P.M.; JORGE, N. Compostos fenólicos em alimentos-uma breve revisão. Revista do Instituto Adolfo Lutz, São Paulo, v.66, n.1, p.0109, 2007.

AOAC - Association of Official Analytical Chemistry. Official methods of analysis of the Association of Official Analitical Chemistry. 19th ed. Washington, 2012

BRASIL. Ministério da Saúde. Agência Nacional de Vigilância Sanitária. Resolução-RDC nº 360, de 23 de dezembro de 2003. Dispõe sobre o regulamento técnico de rotulagem nutricional de alimentos embalados. Diário Oficial da República Federativa do Brasil, Brasília, DF, 17 dez. 2003.

CANUTO, G.A.B.; XAVIER, A.A.O.; NEVES L C.; BENASSI, M.T. Caracterização físico-química de polpas de frutos da Amazônia e sua correlação com a atividade anti-radical livre. Revista Brasileira de Fruticultura, Jaboticabal, v.32, n.4, p.1196-1205, 2010. (1)

CARNEIRO, T.B.; CARNEIRO, J.G.M. Frutos e polpa desidratada buriti (Mauritia flexuosa l.): aspectos físicos, químicos e tecnológicos. Revista Verde, Mossoró, v.6, n.2, p.105-111, 2011.

CASTRO, D.S.; SOUSA, E.P.; NUNES, S.J.; SILVA, L.M.M.; MOREIRA, I.S. Caracterização física e físico-química de polpa de buriti (Mauritia flexuosa). Revista Verde, Mossoró, v.9, n.2, p.117 - 120, 2014.

COUTO, M.A.L; CANNIATTI-BRAZACA, S.G. Quantificação de vitamina $\mathrm{C}$ e capacidade antioxidante de variedades cítricas. Ciência e Tecnologia de Alimentos, Campinas, v.30, Supl 1, p.15-19, 2010.

DELGADO, C.; COUTURIER, G.; MEJIA, K. Mauritia flexuosa (Arecaceae: Calamoideae), na Amazonian palm with cultivation purposes in Peru. Fruits, Les Ulis, v.62, p.157-169, 2007.
DUARTE-ALMEIDA, J.M; SANTOS, R.J.D.; GENOVESE, M.I.; LAJOLO, F.M. Avaliação da atividade antioxidante utilizando sistema b-caroteno/ ácido linoleico e método de sequestro de radicais DPPH • Ciência e Tecnologia de Alimentos, Campinas, v.26, n.2, p.446-452, 2006.

FELLOWS, P.J. Tecnologia do processamento de alimentos: princípios e prática. São Paulo: Artmed, 2006. 602p.

FRANÇA, L.F.; REBER, G.; MEIRELES, M.A.A.; MACHADO, N.T.; BRUNNER, G. Supercritical extraction of carotenoids and lipids from buriti (Mauritia flexuosa), a fruit from the Amazon region. The Journal of Supercritical Fluids, New York, v.14, p.247-256, 1999.

IAL - Instituto Adolfo Lutz. Métodos físicoquímicos para análise de alimentos. São Paulo: Instituto Adolfo Lutz, 2008. 1020p.

ILLUPAPALAYAM，V.V.; SMITH，S.C.; GAMLATH, S. Consumer acceptability and antioxidant potential of probiotic-yogurt with spices. LWT-Food Science and Technology, Amsterdam, v.55, n.1, p.255-262, 2014.

ITTO, S.; AIBA, M.; ISHIHATA, K. Ascorbic acid content in acerola fruit from different production regions and degrees of maturity, and stability during processing. Journal of Japanese Society of Food Science and Technology, Tokyo, v.37, n.9, p.726729, 1990.

LIMA, A.L.S.; LIMA, K.D.S.C.; COELHO, M.J.; MICJELE, J.; SILVA, R.L.D.O.G.; PACHECO, S. Avaliação dos efeitos da radiação gama nos teores de carotenóides, ácido ascórbico e açúcares do fruto buriti do brejo (Mauritia flexuosa L.). Revista Acta Amazônica, Manaus, v.39, n.3, p.649-654, 2009.

LIMA, D.M. Tabela brasileira de composição dos alimentos. versão II. 2.ed. Campinas: NEPAUNICAMP, 2006.

LOUREIRO, M.N.; FIGUEIREDO, R.M.F.; QUEIROZ，A.J.; OLIVEIRA， E.N.A. Armazenamento de buriti em pó: efeito da embalagem nas características físicas e químicas. Bioscience Journal, Uberlândia, v.29, n.5, p.1092-1100, 2013. 
MAGRO, N.G.D.; COELHO, S.R.M.; HAIDA, K.S.; BERTÉ, S.D.; MORAES, S.D. Comparação físicoquímica de frutos congelados de Butiá (eriospatha (mart.) becc.) do Paraná e Santa Catarina - Brasil. Varia Scientia, Cascavel, v.6, n.11, p.33-42, 2006.

MANHÃES, L.R.T. Caracterização da polpa de buriti (Mauritia flexuosa, Mart.): um potente alimento funcional. 2007. 78 f. Dissertação (Mestrado) - Universidade Federal Rural do Rio de Janeiro, Rio de Janeiro, 2007.

MARIATH, J.G.; LIMA, M.C.; SANTOS, L.M. Vitamin A activity of buriti (Mauritia vinifera Mart) and its effectiveness in the treatment and prevention of xerophthalmia. The American Journal of Clinical Nutrition, New York, v.49, n.5, p.849853, 1989.

PACHECO, E.R.; SEROPÉDICA, A.D. Adaptação do método de extração de carotenóides para escala de micro-extração. In: REUNIÃO DE BIOFORTIFICAÇÃO, 4., 2011, Teresina. Anais... )

SAMPAIO, M.B.; SCHMIDT, I.B.; FIGUEIREDO, I.B. Harvesting effects and population ecology of the Buriti palm (Mauritia flexuosa L. f., Arecaceae) in the Jalapão Region, Central Brazil. Economic Botany, Washington, v.62, n.2, p.171-181, 2008

SILVA, M.R.; LACERDA, D.B.C.L.; SANTOS, G.G.; OLIVEIRA, D.M.M. Caracterização química de frutos nativos do cerrado. Ciência Rural, Santa Maria, v.38, n.6, p.1790-1793, 2008.
SOUSA, C.D.M.; SILVA, H.R.; VIEIRA JUNIOR, G.M.; AYRES, M.C.C.; COSTA, C.D.; ARAÚJO, D.S. Fenóis totais e atividade antioxidante de cinco plantas medicinais. Química Nova, Jaboticabal, v.30, n.2, p.351-355, 2007.

SOUSA, F.C.; MELO SILVA, L.M.; CASTRO, D.S.NUNES, J.S.; SOUSA, E.P. Propriedades Físicas e Físico-químicas de polpa de Juazeiro. Revista Verde de Agroecologia e Desenvolvimento Sustentável, Mossoró, v.8, n.2, p.68-71, 2013.

TAVARES, M.; AUED-PIMENTEL, S.; LAMARDO, L.C.; CAMPOS, N.C.; JORGE, L.I.; GONZALEZ, E. Composição química e estudo anatômico dos frutos de buriti do Município de Buritizal, Estado de São Paulo. Revista do Instituto Adolfo Lutz, São Paulo, v.62, n.3, p.227-232, 2003.

UCHOA, A.M.A.; COSTA, J.M.C.; MAIA, G.A.; SILVA, E.M.C.; CARVALHO, A.D.F.F.U.; MEIRA, T.R. Parâmetros Físico-Químicos, Teor de Fibra Bruta e Alimentar de Pós Alimentícios Obtidos de Resíduos de Frutas Tropicais. Segurança Alimentar e Nutricional, Campinas, v.15, n.2, p.58-65, 2008.

VARGAS, P.N.; HOELZEL, S.C.; ROSA, C.S. Determinação do teor de polifenóis totais e atividade antioxidante em sucos de uva comerciais. Alimentos e Nutrição, Araraquara, v.19, n.1, p.11-15, 2008.

YAMASHITA, F.; BENASSI, M.D.T.; TONZAR, A.C.; MORIYA, S.; FERNADES, J.G. Produtos de acerola: estudo da estabilidade de vitamina $C$. Ciência e Tecnologia de Alimentos, Campinas, v.23, n.1, p.92-94, 2003. 